\title{
The Effect of the Seven Chakras on the Colors and Architecture of Ancient Iran
}

\author{
Seyed Kasra Mirpadyab ${ }^{1, ~ *, ~ S o m a y e h ~ S h i r i n j a n i ~}{ }^{2}$, Elham Goljamali ${ }^{3}$ \\ ${ }^{1}$ Department of Architecture, Faculty of Architecture and Urban Planning, Qazvin Branch, Islamic Azad University, Qazvin, Iran \\ ${ }^{2}$ Department of Architecture, Faculty of Architecture, Islamic Azad University Ahvaz Branch, Ahvaz, Iran \\ ${ }^{3}$ Department of Architecture, Faculty of Architecture, Islamic Azad University Nour Branch, Mazandaran, Iran
}

Email address:

kasrapadyab@yahoo.com (S. K. Mirpadyab)

${ }^{*}$ Corresponding author

\section{To cite this article:}

Seyed Kasra Mirpadyab, Somayeh Shirinjani, Elham Goljamali. The Effect of the Seven Chakras on the Colors and Architecture of Ancient Iran. American Journal of Art and Design. Vol. 5, No. 4, 2020, pp. 78-86. doi: 10.11648/j.ajad.20200504.11

Received: September 16, 2020; Accepted: October 5, 2020; Published: November 4, 2020

\begin{abstract}
In this paper, we intend to study fine examples of Islamic-Iranian architecture prove that the people was aware of the chakra's seven chakras and their attributes and therefore the impact is evident in the architecture. In a comparative study of six by six Persian style, party, Khorasani, mystery, Azeri and selected Isfahani The impact on them was seven chakras and the end of the article is to explore the three effects in both the time before and after the advent of Islam was taken. First, after the arrival of Islam in Iranian architecture, due to open third chakra, fifth, sixth, and seventh shifted. And secondly, the pre-Islamic Persian architecture according to the first chakra and the fourth chakra (see the green of nature and hear the sounds of nature from inside the building) was paid in the third period no reason to focus on the second chakra sex (no orange) is not. As well as by matching the dimensions of the human body chakras in the human body have got to the point that the golden proportion is derived from the human body chakras. In the end, we have come to the conclusion that in the architecture of Iran before the advent of Islam and even after the advent of Islam, whether in meaning and content, or in the form of form, or in space and decorations, the color orange has not been used at all. In the description of the second chakra meaning lust, architects have not used this color in architecture.
\end{abstract}

Keywords: Islamic and Iranian Architecture, Chakras of the Human Body, Relationships, Body Dimensions, The Golden Proportion

\section{Introduction}

Do you understand that according to verse 143 of Sura Araf Iranian - Islamic architecture theory offers a manifestation of the image $[6,2]$ will be only three instruments and ways of human perception of the senses, the intellect, and the soul (heart John, heart) relied on upon? And whether it is possible to open the chakras by color in architecture was originally manifested? Are the colors used in the designs of Persian Islamic architecture with colors that open communication with the body chakras see them? Are amplify the voices in Islamic architecture has to open chakras. Is Bagh in Islamic architecture and naturally get the sound nature of Islamic architecture a way to open the first chakra user space, is human. And whether the silent sanctuary and dome were to open the seventh chakra is there a pool and fountains and waterways and breast Quebec (the reflection of the sky in water) in Islamic architecture has been to open the fifth chakra? Is the relationship between the chakras of the human body and the golden proportions of the human body there?

The history of color in Islamic thought and civilization begins with the Qur'an in a sense symbolic illustration Paradise using the color of happiness and beauty of creation, such as yellow, green, white, and red to accomplish that, however much charm carries the soul of the observer [6]. Chakras, or energy centers, contact points are that its energy from one body to another human body flows. Who has little 
personal insights; can easily see in the ether body; they see themselves as plate-like recesses or vortices in the etheric body show. If that were not evolved (i.e. the common man) as a small circle with a diameter of approximately $5 \mathrm{~cm}$ and appear luster and little motor But when activated, glowing like a flaming vortex that is much larger and looks like a small sun. Sometimes it as something similar physical characteristics limbs talk but in fact, your etheric double of the show that is somewhat beyond the dense body [5]. Chakras are a basic concept of yoga but typically are ignored by scientific research on yoga, Chakras are commonly considered to be centers of concentrated metaphysical energy [16].

\section{Freedom Chakras}

Step seven chakra therapy includes aromatherapy, herbs, minerals (Stone Therapy) therapeutic mud (known as the discoverer of Bach) Bach (Bachblueten Therapy), vibrations letters, sentences powerful affirmation, meditation, and energy through the floor hands $[4,13]$.

\section{They Describe the Chakras and Activation Measures}

\subsection{First Chakra}

Root, The number of petals: 4 lotus petals, Red color, Primordial elements: earth, Basic symbol: Square, Mercury, Intuitive operation: the olfactory, The respective metal: lead $[4,12,13]$.

The first center, the base chakra located at the base of the spine and raw energy that is radiated out with a four-bladed as a result, its waves are organized in a way that seems to be the center of the four quadrants, with the appearance and frequency of red and orange and troughs are divided between them. This makes it seem as if the cross is marked with the sign of the cross as so often this symbol is used chakra; sometimes also representative of a cross-ignite the Fire Pit and is housed, used as a symbol of the chakra. When this chakra is activated, the orange color - fiery red because of the match with the kind of energy that is sent to it by the spleen It should be noted that each color corresponds to the energy of the chakras may be seen [5].

Ways to Enable Root Chakra

A: Color Therapy

T-shirts or red clothes or muddy purchase and pay attention to the color and light music to listen to

(B) enjoy the sun and the sun

A: Stone therapy

Precious mineral stones such as onyx, rubies and regularly in touch daily

D: Aromatherapy

Vegetable oils: rosemary, clove oil, cedar, cypress oil

At work or in your home this chakra is related to the use of aromatic oils plant.

(C) Permanently to walk and some fresh air, as well as how often, walk on foot to do $[4,12,13]$.

\subsection{Second Chakra: Spleen}

The number of petals: 6 numbers lotus flower petal, Orange, Primordial element: Water, Symbol: Month, Planet: Venus, Intuitive operation: the sense of taste, The respective metal: Iron

The second center, the spleen, the spleen, the allocation, segmentation, and analysis of vital energy that reaches us from the sun, is dedicated. This vital energy from this chakra again in six horizontal streams flowing out; the seventh flow is depicted in the center of the wheel. So, this energy center has six petals, with different colors and shines like the sun. Each of the six-segment color wheel of one of the vital energy for most of the show: red, orange, yellow, green, purple, and blue $[5,14,15]$.

Ways to Stimulate the Spleen Chakra

A: Color Therapy

Use of orange in your life, for example, the desktop Orange with orange flowers and a bowl of oranges on the fun and stimulate your second chakra

B: Stone therapy

Energy stones such as amethyst and opal orange fire to spread quickly and easily to the body and better energy during the day by touching the stones in the body and convey your second chakra Of course, this transfer is done palm chakra.

\subsection{Third Chakra: Solar Plexus (Navel)}

The number of petals: 10 lotus petals

Color: golden, yellow, golden yellow

Primordial element: fire

Symbol: triangle

Planet: Mars

Five senses: Sight [4].

The third center, umbilical, near the navel or solar plexus, and raw energy of the radiation received and why it is so vibrant that it seems wave is divided into ten or petals. The center has a close relations with emotions differently. The dominant color palette that rare combination of red and green in there a lot. Divided sections in the form of alternating red and mostly green or mostly (Lydybtr, Webster, 1386, p. 18)

"They pray to our Lord shows us what color he says it is a yellow cow bright color gone viewers," They ask the Lord clear to us of what color she that said: He says the heifer yellow color uniform and pure that makes viewers happy. [6]

Ways to Enable Third Chakra Navel

A: With Fire and flame closely together, on the fireplace to sit and yellow flame color look at it and otherwise at least a candle for light and flame fun

B: Color Therapy

Bring Yellow color into your life and buy clothes and yellow walls with yellow flowers like sunflowers Yellow tulip or decorate your living room table or a lemon yellow 
dish on the table.

D: Stone therapy

Another mineral ores this chakra is also lapidary Bernstein (turned to stone) of gum obtained fir trees and to touch up during the day and recommend affect the third chakra energy. Because stones named through the palm chakras of the body better every day lasts longer in our hands touch the rocks.

E: always be prepared for sunbathing and sun and when you use it with this chakra to the good sense of the warmth of the sun and solar energy in your third chakra $[14,15]$.

\subsection{The Fourth Chakra Heart}

The number of petals: 12 Petals (Lilies), Color: Green, Primordial elements: air (oxygen), The main symbol: Hexagon Star of David, Planet: Jupiter, Intuitive operation: touching [4].

The fourth center, the heart, the heart is located in the area. The radiant golden color and each quadrant arisivided into three parts in total, 12 of finds. For this reason the primary energy for the twelve feathers. [5]

\section{Way Enable Fourth Chakra}

A: use stone emerald and pink quartz in ways that keep them in touch palms of course, in a way that exactly is in contact with the palm chakras

B: Day Wear green clothes and green plants inside the home, also in decorating cloth and use green materials

\subsection{The Fifth Chakra, Throat}

The fifth center, the laryngeal, throat and has sixteen spokes, and therefore sixteen specific rates of the appropriate section of blue in it, but the general appearance of silver and flicker, like the reflection of the moon on water waves of blue and green hihighlight, can be seen regularly on its components. [5, 14].

The number of petals: 16 lotus petals, Color: pale blue, Primordial elements: ether, The main symbol: the circle, The planet: Saturn, The five senses: hearing $[4,11,12]$.

Five Ways to Activate Chakras

A) Stone therapy

Lapi-lapis stone as a stone would recommend that you keep in touch this energy is transferred into the body through the hands and better extended periods in hand to touch it

B) Use of blue in your life. Wearing blue overalls and blue scarves use of bath towels and blue decorate your bathroom environment.

C) nature and look to seeking natural colors such as sky blue and sea pay

\subsection{The Sixth Chakra Eyes}

The number of petals: $2 x$ lotus petals, Color: dark blue, indigo blue (cyan), Primordial element: -, Basic symbol: a winged circle, Uranus, Five sense: seventh sense (sense of metaphysics), [4].

The sixth center, located in the forehead between the eyebrows On the surface it seems that the center is divided into two halves, half mainly with red paint with lots of yellow paint around it and the other half dominated by the color blue to a purple color for powering vital energy which they correspond. Perhaps that is why Hindi books listed in this center have only two petals. But if the waves were calculated in the same way that the previous center, count, we see that each half to forty-eight sections and a total of ninety-six part forms, for this reason, the initial energy of its radius.

The unexpected jump from 16 to 96 blades and even more so from 96 to 927 in the next chakra, to show us that the centers are generally different from those that had looked at, are facing. We are all factors that determine the number of spokes on a Chakra are, do not know, but this is so obvious that they are about primary energy, show differences. (Lydybtr, Webster, 1386, p. 19)

Ways of Activating the Sixth Chakra

A) Use Dark blue or turquoise dress for your purchase of desktop and utensils and napkins and towels to use this color.

Use color.

B: Aromatherapy

Some of the aromatic oils can have a significant impact on balancing the energy in the chakras sixth respective name of this oil cajuput., Lemongrass, veil hen is.

You can own the oil in place of incense candle scented oils in the room or your work environment. [4, 12, 13].

\subsection{The Seventh Chakra Crown}

The seventh center, Taji, islocated at the top of the head, when fully activate the maximum brightness, color range, and vibration indescribable and incredible speeds. It sounds like all kinds of prismatic colors, but purple on its own in the works is a prominent Hindi is described as a thousand petals, which is not too far from the truth because of its initial energy within the outer circle is 960 . This particular form apart from other Chakras Chakra is a sub-center ring in white, tinged with a golden color in the center of the wave dozen of its own and is less activity [5, 14]. The number of petals: petals of the lotus 1000, Color: purple, white or golden, Primordial element: Basic symbols: Lily, Planet: Neptune, The five senses: cosmic consciousness [4].

Ways to Activate Seventh Chakras

A: Color Therapy

utilizing the chakra and seeing them not paint your room

Often desk room or your workplace pot of flowers White roses or Margaret or Lilium white or Lilium purple or flowers variety of colors white or purple paste and have fun

B: Stone therapy

Crystalline quartz and amethyst are suitable both for touch up during the day and for the activation energy in this chakra are suggested

$\mathrm{C}$ : Day prepare yourself to understand the power of silence $[4,12,13]$.

The seven main chakras are shown in the following figure. (Figure 1). 

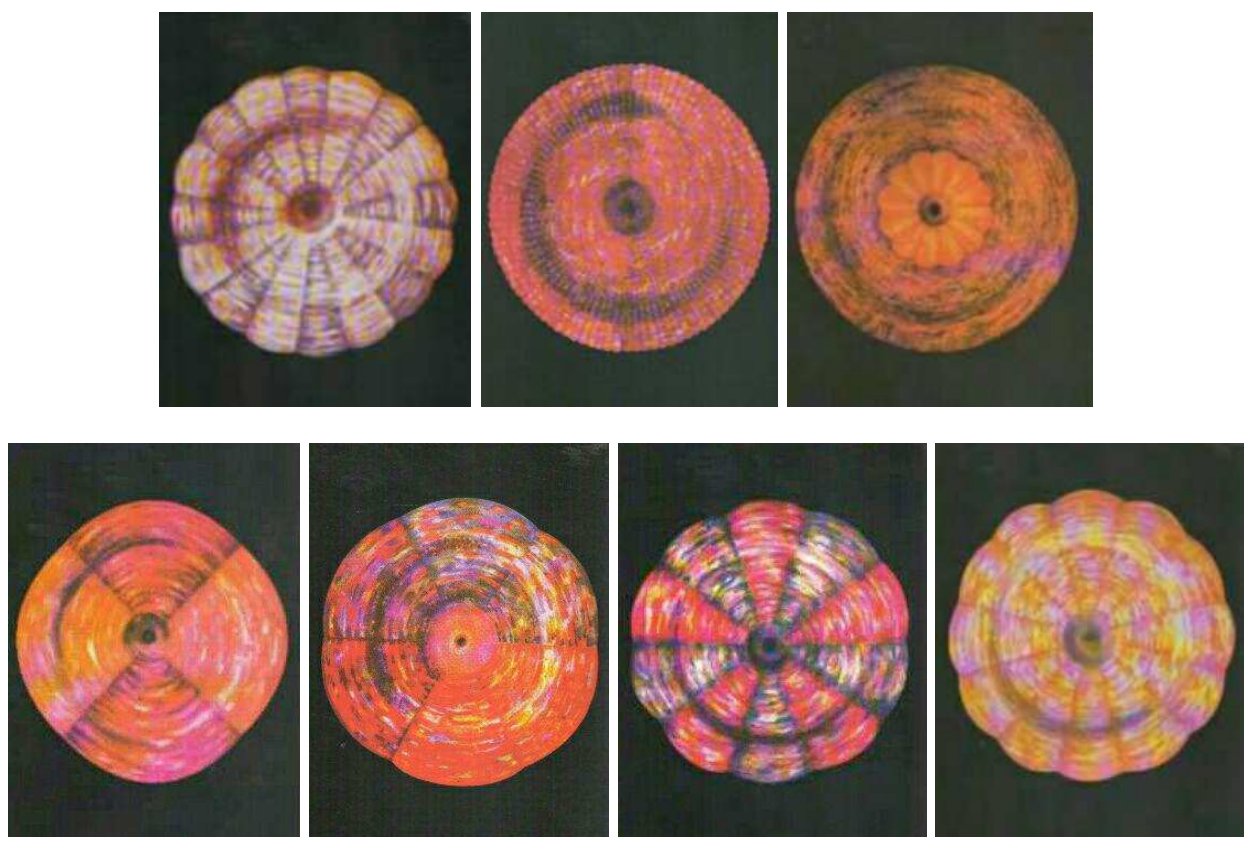

Figure 1. In the top row from left to right: Humans and seven chakras the crown chakra, chakra, brow, throat chakra.

Bottom row from left to right: heart chakra, navel chakra (solar), spleen chakra, the root chakra

\section{Matching Relations with the Chakras, Body Dimensions}

The oldest and most famous measure of human relationships secret room was discovered burial pyramids near Memphis that it almost goes back to $3000 \mathrm{BC}$.

Surely it is time ever, scientists and artists trying hard to obtain the relative relationships of man. (Nyvfrt, 2006, p. 21)

If the above body dimensions as the history of relations between scientists and artists on the little information we can focus our attention on the human body As a user of the building are aware of the necessity of understanding the human body and its chakras becomes clearer The implementation of the location of the chakras with lines drawn between body size is important. (Image 2)

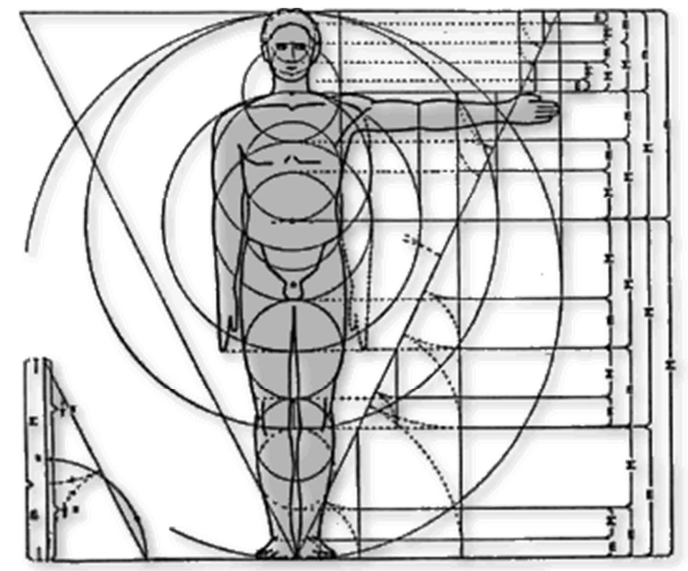

Figure 2. Matching dimensional relations with the chakras in the human body [3].

\section{Why It Matters}

So far, all great architecture and Islamic Iranian architecture have tried to explain in this way the great architects such as Doctor Karim Pirnia Iranian-Islamic architecture style into six Persian, Parthian, Khorasani, mystery, Azerbaijan, and Isfahan have split. Unfortunately, in this regard, none of the architect's attempts at resuscitation has left seven missings. We hope that by understanding the hidden dimensions of human and their Chakra as a continuous chain of Islamic architecture, the user can restore the building and understanding than we find architecture without architects

\section{Literature}

In the Quran, as well as Pythagorean science of music has pointed to the existence of chakras and each also features an article entitled ((impact yoga program executive actions the youth living in orphanages)) suggests the existence of chakras of the human body has been found.

\subsection{Practical Exercises Open the Chakras, Orphans, in the Orphanage This Research in a Paper}

Chakra Yoga is a series of exercises through which seven main chakras in our energy body will grow and evolve with the flow of energy that power.

In an article entitled ((impact yoga program executive actions the youth living in orphanages)) in the three months to test the impact of yoga on the EF had studied It was found that yoga can be used as a tool in orphanages. [1].

However, one of the reasons for the weak or blocked chakra (root chakra) is usually related to childhood and People who have had a lot of neglect or have been abandoned to orphanages or foster care and Or children who I nickname, 
given to them is unwanted or illegitimate or even in children or adolescents who have been sexually exploited. So these people have less trust in others and cannot live easily and with confidence.

The children who are born in the lap of a family torn apart and bred contains this group (fourth chakra blockages), they always lived alone or with a parent's lack of affection from his father or mother and they feel life is always a lack of love toward others for the apparent duplication and align. [4, 1113].

Do you have high self-activate chakras first and fourth chakra orphaned youth to succeed?

Is architecture can be closed with the knowledge of chakras' first and fourth chakra orphans in the orphanage architecture to open the chakra lead?

\subsection{The Qur'an Verses That Seven of Them Have Been Used for This Purpose}

«And if the land but in the sea of Attune and provide him with a tree after him seven sailed Manfdt I promised God that God is Mighty, Wise; [2]

And if all the trees on earth were pens and the sea, with seven more seas to help it, the words of God will not be exhausted. Surely Allah is Mighty, Wise. [2]

\subsection{The Impact of Chakra Music}

Pythagoras invented the science of music. He coordinated the science of celestial sounds that they hear His exact nature and reason were genuine gains. This analogy is discussed in detail. For example, 12 officials, seven sounds, 24 brbranches, and 48 combined, in acaccordance with signs of the zodiac, planets, night and days, and weeks are the lunar year. [7].

\section{Objectives and Research Areas}

In explaining the purpose of proving the effectiveness of these article three chakras in architecture and its relationship with the golden ratio is considered.

\section{Research Method}

This article is a comparative while the choice of the building has six different styles in different eras, but the similarity with human analysis is based on the chakras. (Table 1)

\section{Findings}

Table 1. Comparison and adaptation of ancient Iranian monuments with body chakras.

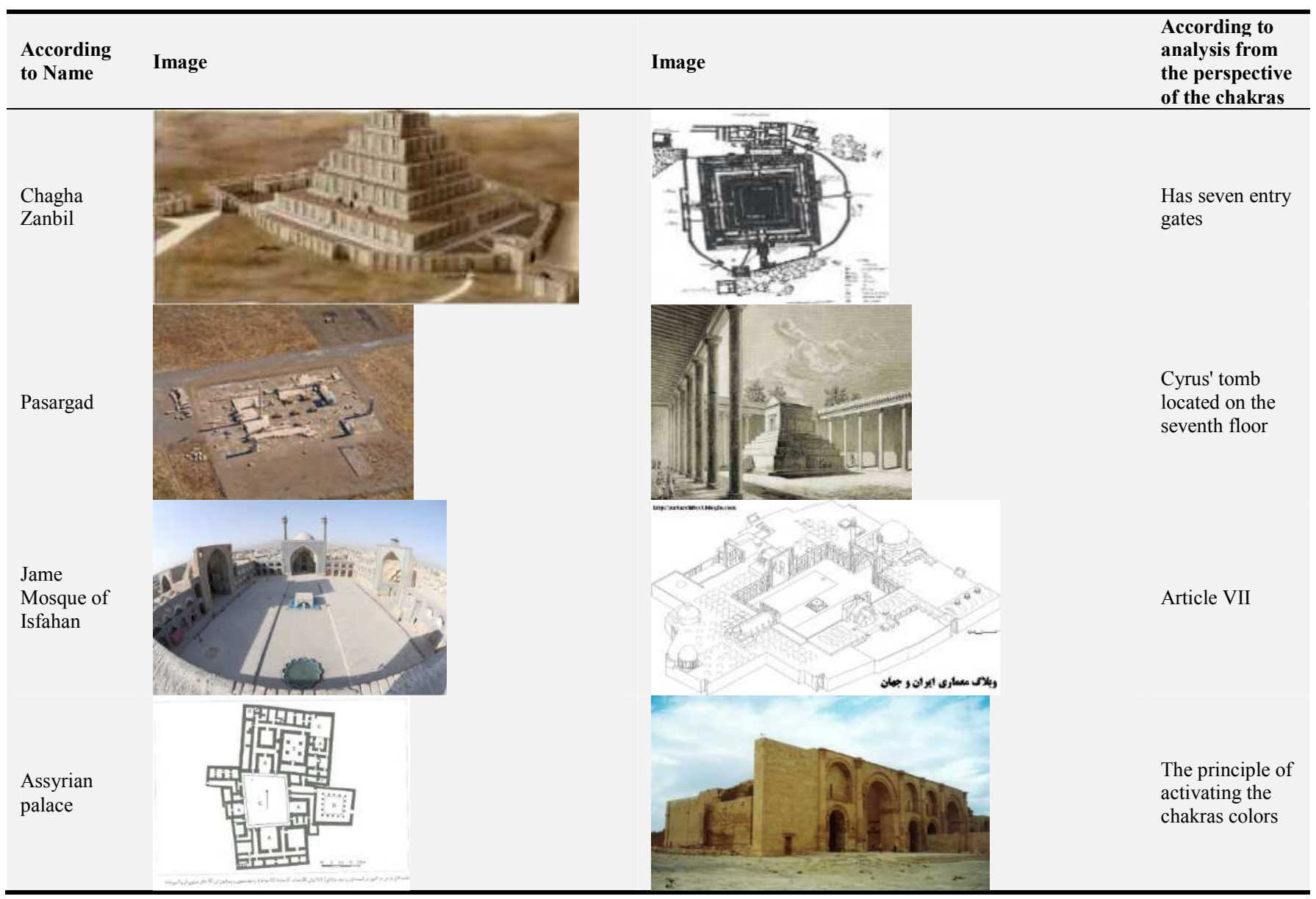




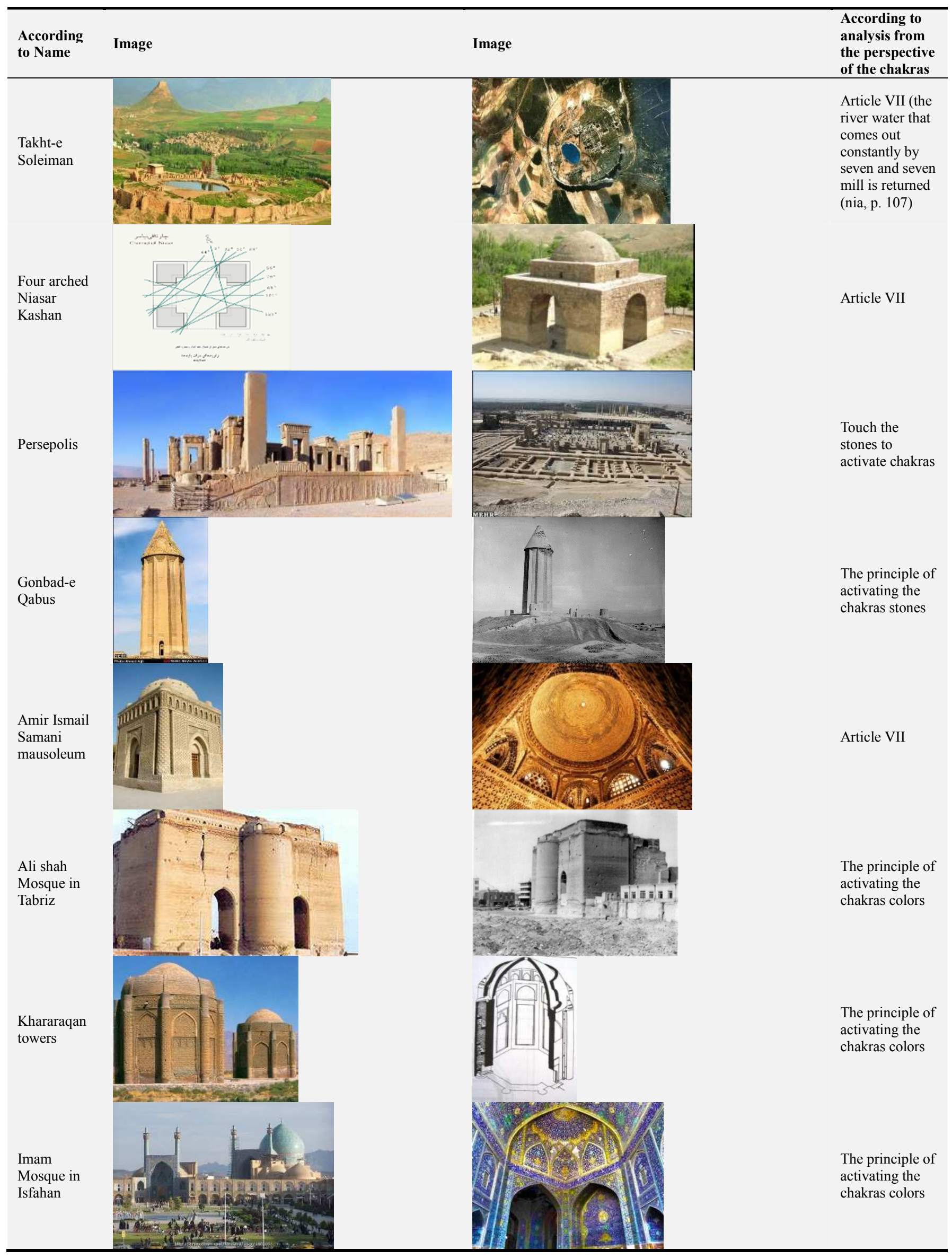




\begin{tabular}{|c|c|c|c|}
\hline $\begin{array}{l}\text { According } \\
\text { to Name }\end{array}$ & Image & Image & $\begin{array}{l}\text { According to } \\
\text { analysis from } \\
\text { the perspective } \\
\text { of the chakras }\end{array}$ \\
\hline $\begin{array}{l}\text { Arvestan } \\
\text { Palaces }\end{array}$ & & & Article VII \\
\hline $\begin{array}{l}\text { Four of } \\
\text { school } \\
\text { gardens }\end{array}$ & & & $\begin{array}{l}\text { Article VII } \\
\text { +original colors } \\
\text { of the chakras } \\
\text { active }\end{array}$ \\
\hline Damghan & & & $\begin{array}{l}\text { The principle of } \\
\text { activating the } \\
\text { chakras colors }\end{array}$ \\
\hline $\begin{array}{l}\text { Blue } \\
\text { Mosque of } \\
\text { Tabriz }\end{array}$ & & & $\begin{array}{l}\text { The principle of } \\
\text { activating the } \\
\text { chakras colors }\end{array}$ \\
\hline $\begin{array}{l}\text { Mosque } \\
\text { Ardestān }\end{array}$ & & & $\begin{array}{l}\text { The principle of } \\
\text { activating the } \\
\text { chakras colors }\end{array}$ \\
\hline $\begin{array}{l}\text { Soltanieh } \\
\text { Dome } \\
\text { Zanjan }\end{array}$ & & & $\begin{array}{l}\text { The principle of } \\
\text { activating the } \\
\text { chakras colors }\end{array}$ \\
\hline $\begin{array}{l}\text { Anahita } \\
\text { Temple } \\
\text { Kangavar }\end{array}$ & & & $\begin{array}{l}\text { Touch the } \\
\text { stones, opening } \\
\text { the chakras }\end{array}$ \\
\hline $\begin{array}{l}\text { Sheikh } \\
\text { Lotfollah } \\
\text { Mosque }\end{array}$ & क) & & $\begin{array}{l}\text { The principle of } \\
\text { activating the } \\
\text { chakras colors }\end{array}$ \\
\hline
\end{tabular}


Table 2. Matching table, six Iranian architecture style buildings with Chakra.

\begin{tabular}{|c|c|c|c|c|c|c|c|c|}
\hline $\begin{array}{l}\text { According } \\
\text { Name }\end{array}$ & The style & $\begin{array}{l}\text { The first } \\
\text { chakra (red) }\end{array}$ & $\begin{array}{l}\text { The } \\
\text { second } \\
\text { chakra } \\
\text { (orange) }\end{array}$ & $\begin{array}{l}\text { The third } \\
\text { chakra } \\
\text { (yellow) }\end{array}$ & $\begin{array}{l}\text { The fourth } \\
\text { chakra } \\
\text { (green) }\end{array}$ & $\begin{array}{l}\text { The fifth chakra } \\
\text { (aqua) }\end{array}$ & $\begin{array}{l}\text { The sixth } \\
\text { chakra (dark } \\
\text { blue, indigo } \\
\text { blue) }\end{array}$ & $\begin{array}{l}\text { The seventh } \\
\text { chakra (white, } \\
\text { purple) }\end{array}$ \\
\hline Pasargad & Persian & $\begin{array}{l}\text { Walking in } \\
\text { naturein front } \\
\text { of Pasargadae } \\
\text { (waterand } \\
\text { fountains and } \\
\text { water divider } \\
\text { rocky tracks) } \\
\text { And opening } \\
\text { the first } \\
\text { chakra }\end{array}$ & ------- & $\begin{array}{l}\text { Fire } \\
\text { Pasargadae } \\
\text { (see the flame, } \\
\text { which prevents } \\
\text { opening of the } \\
\text { third chakra) }\end{array}$ & $\begin{array}{l}\text { Being } \\
\text { erected in } \\
\text { the green } \\
\text { nature }\end{array}$ & $\begin{array}{l}\text { Fire Pasargadae } \\
\text { (without roof and } \\
\text { see my name in } \\
\text { blue and the } \\
\text { opening of the } \\
\text { fifth chakra) }\end{array}$ & & \\
\hline $\begin{array}{l}\text { Assyrian } \\
\text { palace }\end{array}$ & Parthian & & ------- & $\begin{array}{l}\text { Building a } \\
\text { wholly-yellow } \\
\text { colored earth }\end{array}$ & & & & $\begin{array}{l}\text { Assyrian palace } \\
\text { nested in the quiet } \\
\text { spaces }\end{array}$ \\
\hline $\begin{array}{l}\text { Mosque } \\
\text { Ardestān }\end{array}$ & Razi & & ------- & $\begin{array}{l}\text { Building a } \\
\text { wholly-yellow } \\
\text { colored earth }\end{array}$ & & & & $\begin{array}{l}\text { Nested in the quiet } \\
\text { spaces mosque }\end{array}$ \\
\hline $\begin{array}{l}\text { Zanjan } \\
\text { Soltanieh } \\
\text { tomb }\end{array}$ & Azeri & & ----- & $\begin{array}{l}\text { Yellow earth } \\
\text { materials }\end{array}$ & $\begin{array}{l}\text { Being } \\
\text { erected in } \\
\text { the green } \\
\text { nature }\end{array}$ & $\begin{array}{l}\text { Soltanian Dome } \\
\text { Zanjan blue }\end{array}$ & & $\begin{array}{l}\text { Input from the top } \\
\text { of the dome white } \\
\text { eyelet }\end{array}$ \\
\hline $\begin{array}{l}\text { Sheikh } \\
\text { Lotfollah } \\
\text { Mosque }\end{array}$ & Isfahanian & & ------ & $\begin{array}{l}\text { Yellow in the } \\
\text { dome }\end{array}$ & & $\begin{array}{l}\text { Light blue color } \\
\text { in the verses }\end{array}$ & $\begin{array}{l}\text { Indigo on the } \\
\text { side of verses }\end{array}$ & $\begin{array}{l}\text { Input from the top } \\
\text { of the dome white } \\
\text { eyelet }\end{array}$ \\
\hline
\end{tabular}

\section{Discussion and Conclusion}

In this paper, six belonging to six styles of Persian, Parthian, Khorasani, mystery, Azeri and Esfahani randomly selected and assessed and evaluated the impact of the seven chakras and in the end led to the following conclusions.

1. After the arrival of Islam in Iranian architecture, considering the third chakra, fifth, sixth, and seventh shifted.

2. The pre-Islamic Persian architecture according to the first chakra and the fourth chakra (see the green of nature and hear the sounds of nature from inside the building)

3. In any given period due to sexual chakra is the second Iranian-Islamic architecture yet.

4. Relations have been chakras of the human body.

\section{Offers for Future}

1. Humans and their chakras, as a user of architectural space, to train architects.

2. The impact of widely consider chakras in the Persian architecture

3. Having regard to the course of the six chakras can Iranian architectural Persian, Parthian, Khorasani, Azeri and Persian architecture revive the lost Esfahani assess the seventh loop.

4. An in-depth study shows the presence of archetypes
Milky Way in architecture around the world because of this rotating disk in the entire human body.

5. Through extensive research to show the lack of orange in Islamic architecture because it belongs to the sexual chakra and the animal is human. However, many studies have shown a difference in perceptions between men and women $[8,10]$. but Researchers have found, also the relationship between sexuality and lust with architectural design and color and different gender in perception [9].

6. Evaluation of organic architecture to conclude that organic architecture is the perfect answer to the first and fourth chakra. Therefore, every person of every religion and mind through organic architecture, which prevents opening of the first and fourth chakra, will have a good sense of the architecture.

7. In-depth analysis of the relationship golden proportions of the human body chakras and communication architecture with Gothic windows Golsorkhi deal with the human body rotating discs.

\section{References}

[1] Effect of yoga program on executive functions of adolescents dwelling in an orphan home: A randomized controlled study, by Satya Prakash Purohit, Balaram Pradhan, India, 2016.

[2] Quran, Elahi Ghomsheie, Omran Printing, 1387. 
[3] Information Architects' Data Architecture (2008), translated Kouroosh Mahmoodid deh Bigelow, Tehran, future CounterCity Water, 1386.

[4] Kalashatra Gavin Da, Atlas chakra, translation M. East, Mashhad Sun Flower Press, 1395.

[5] Seven chakras produce more, Charles Webster, translation Mojgan. Sharifi, Tehran, Publishing Triangle in 1386.

[6] Bolkhari Qehi, H., 1394, as the theory of art and beauty in Islamic civilization, Tehran, Navideshahed.

[7] Manifestations of spiritual wisdom in Islamic art, Mohammad Madadpur Tehran, international Nshrbyn, 1387.

[8] Mirpadyab, Seyyed Kasra, (2020) Teaching Architectural Design Thinking In line with Objectivity (Experience) and Subjectivity (Imagination) with an Emphasis on the Gender Differences in Students' Perceptions of the Built Environment". Ph.D. thesis, Department of Architecture, Islamic Azad University of Qazvin.

[9] Mirpadyab, Seyyed Kasra., Zafarmand, E,.(2016) Knowing the physical quality of the Red Light District of Amsterdam (Netherlands) (in Persian language) International Conference on Civil Engineering, Architecture and Urban Cityscape, Istanbul University, Turkey.

[10] Mirpadyab, Seyyed Kasra, (2020) Sex is More: The Relationship between Sexual Satisfaction and Architectural Space Design by Gender Differences in couples Perceptions, revise.

[11] Sharamon, S., \& Baginski, B. (2018). Chakra Handbook. Lotus Press.
[12] Pond, D. (1999). Chakras for beginners: A guide to balancing your chakra energies. Llewellyn Worldwide.

[13] Sherwood, K. (1988). Chakra Therapy: For Personal Growth \& Healing. Llewellyn Worldwide.

[14] Selby, J., \& Selig, Z. (2009). Kundalini awakening: a gentle guide to Chakra activation and spiritual growth. Bantam.

[15] Judith, A. (2012). Wheels of life: A user's guide to the chakra system. Llewellyn Worldwide.

[16] Richard W. Maxwell, 2009 "The Physiological Foundation of Yoga Chakra Expression"; Journal of Religion \& Science and Ruth Stanley, "Types of Prayer, Heart Rate Variability, and Innate Healing".

\section{Biography}

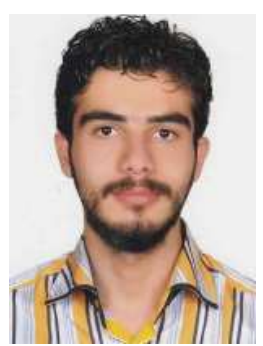

Seyed Kasra Mirpadyab, is an architect, critic, author, and professor of the university is a poet is a successful architect. He is an architect interested in architectural psychology and the world's first specialist couples sex therapist by design. Kasra After a lot of research about Gender Differences of Perception and Architecture, he is now investigating architecture and determining the sex of the fetus and the height of orgasm, sexual satisfaction, and pleasure also sexual behavior and the quality of flirting by space. He is trying to bring about significant changes in architecture with the slogan (Sex Is More). 